klart og greit sammenhengen mellom dødelighet, somatisk og mental helse og utdanning hos så vel barn og ungdom som voksne. Enda bedre, han går gjennom en rekke mulige forklaringsmekanismer og større teorier om hvorfor sosial posisjon og helse henger sammen.

Utdanning og helseulikheter er uvanlig velskrevet. Språket er lett tilgjengelig, og figurer og tabeller er gjennomarbeidet. Den anbefales alle som vil ha en klar og forholdsvis kort innføring i sosiale ulikheter og helse.

\section{Bjørgulf Claussen}

Prosjekt «storbyhelse»

Institutt for allmenn- og samfunnsmedisin Universitetet i Oslo

\section{Liv og død i hospice}

Richardson A

\section{Life in a hospice}

Reflections on caring for the dying Oxon: Radcliffe, 2007. Pris GBP 20 ISBN 978-1-84619-243-2

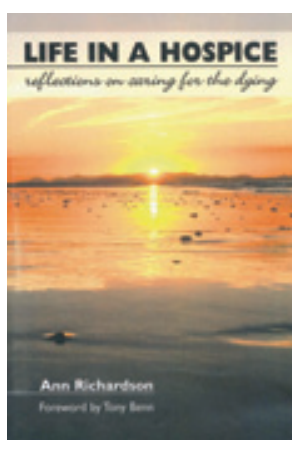

Hospits betyr herberge, men «hospice» ble et eget begrep da Cicely Saunders (1918-2005) startet St. Christopher's Hospice i London i 1967. Målet var å endre dødspleien («care of the dying») til god omsorg ved livets slutt. Før var døden gjemt bort på sykehusene, smertefull og ensom. Nå skulle den preges av «freedom from pain, dignity, peace and calm at the end of life». Omsorgen skulle omfatte de pårørende, som skulle leve med minnene resten av sine liv.

Jeg fikk være med på et besøk til St. Christopher's Hospice i 1974, og jeg glemmer det aldri. Cicely Saunders skapte et helt nytt begrep som har spredt seg til mange land, og det er nå omkring 250 tilsvarende institusjoner i Storbritannia. Hun skrev lærebøker og ble adlet for sin innsats (dame Cicely Saunders).

Her handler det om livet og døden i to utvalgte hospice i England. Ann Richardson er forsker, forfatter og redaktør. Hun har alliert seg med to profesjonelle intervjuere som har snakket med 31 utvalgte ledere, pleiere, leger, representanter for rengjørings- og kjøkkenpersonell og frivillige. Formålet var å beskrive livet og arbeidsdagene: Hvordan det var og hvordan det virket på pasientene, pårørende og alle som arbeidet der. Intervjuene ble tatt opp på bånd og skrevet ut ord for ord.
Etter en kort innledning om hospicebevegelsen er materialet delt i fire deler: Beskrivelse av praksis, utfordringer og løsninger, motivasjon og belønning og til slutt refleksjoner. Hver del inneholder korte kapitler og underkapitler, noe som gjør det lett å følge resonnementene. Teksten er i det alt vesentlige ordrette sitater fra intervjuene med korte innledninger, ofte bare én enkelt setning. Inndelingen av stoffet er logisk og teksten lettlest, men samtidig tankevekkende. Den kombinerer hele tiden fakta og refleksjoner. Ett eksempel er eutanasi, som alle er «very against».

Ett stort og sammensatt tema er: Hva trekker ansatte og frivillige til hospicearbeidet, hvorfor blir de, og hva er de personlige utfordringene og belønningene? Mange er personlig troende, og jeg spurte Cicely Saunders om det var en betingelse. «No,» svarte hun, «but it so happens that most of us are.»

En mangel, i mine øyne, er at det ikke finnes statistikk - verken om pasienter, ansatte eller frivillige. Jeg får et klart inntrykk av at de fleste pasientene har kreft, og det er lite om alle de gamle som ikke dør av kreft. Men jeg er ikke i tvil om at hospicefilosofien kan være en modell for all omsorg ved livets slutt.

Jeg tror at alle leger og sykepleiere som arbeider med dem som nærmer seg slutten på livet, vil ha stor nytte av denne utgivelsen. De vil finne råd, støtte og inspirasjon til denne viktige og vanskelige oppgaven.

\section{Peter F. Hjort}

Blommenholm

\section{Omfattende om hudens immunologi}

Nickoloff BJ, Nestle FO, red. Dermatologic immunity

381 s, tab, ill. Basel: Karger, 2008. Pris CHF 380 ISBN 978-3-8055-8391-6

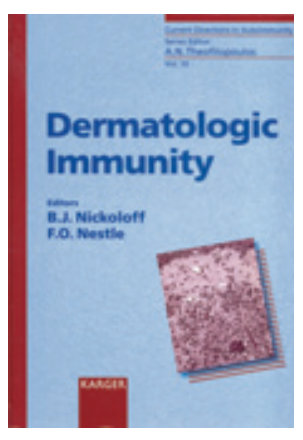

Dermatologic immunity inngår $i$ en serie utgivelser under overskriften Current directions in autoimmunity og omfatter en samling oversiktsartikler som dekker autoimmune tilstander i huden. Begrepet «autoimmune sykdommer» defineres i denne sammenhengen bredt og inkluderer alle kroniske inflammatoriske hudsykdommer uten kjent agens.

Layouten er stram, og det er sparsomt med illustrasjoner og bilder. Alle kapitlene etterfølges av en lang og oppdatert referanseliste.
Det er til sammen 19 kapitler, der det overveiende er omtale av diagnosene enkeltvis. Unntaket er et kapittel om immunologisk privilegerte celler i huden en basal innføring $i$ begrepet som danner utgangspunkt for en hypotese om fremtidig behandling med vekt på alopecia areata. Videre er det et avsluttende kapittel som gir en oversikt over immunmedierte behandlingsprinsipper, inkludert en modell for å forstå immunterapi. Kapitlet gir videre en kort oversikt over angrepspunktene til vanlig brukte medikamenter i behandling av hudsykdommer, fra kortikosteroidene, antimetabolittene (f.eks. metotreksat, azatioprin og mykofenolat mofetil) til moderne biologiske midler, som får stadig større plass $\mathrm{i}$ behandlingen av psoriasis og flere andre hudsykdommer. Mekanismer knyttet til effekt ved bruken av intravenøse immunoglobuliner ved bulløse dermatoser omtales også i et eget kapittel, noe som vel gjenspeiler at det foreløpig ikke er full konsensus om indikasjon og bruk av slik terapi. Kapitlet illustrerer godt at forståelse av sykdommers patofysiologi og medikamenters virkningsmekanisme ofte utvikles parallelt.

De diagnoserelaterte kapitlene, eller rettere sagt artiklene, er noe varierende bygd opp. Enkelte, som for eksempel det som omhandler lichen planus, er overveiende konsentrert om immunpatogenetiske mekanismer, mens man i andre deler knytter immunologisk teori opp mot forståelse av immunterapi. Dette gjelder blant annet artikkelen om psoriasis, der biologiske behandlingsprinsipper i form av monoklonale antistoffer og løselige reseptorer har tilført en ny dimensjon av muligheter for hardt rammede.

Det komplekse samspillet mellom immunologi og genetikk illustreres godt ved at en sykdom som vitiligo er viet to kapitler, ett som omhandler genetikk, et annet med autoimmun etiologi i overskriften.

Atopisk dermatitt omtales nokså bredt, og relativt nye begreper som «intrinsic») og «extrinsic» atopisk dermatitt diskuteres. Forfatteren illustrerer dessuten godt dilemmaet omkring diagnostikk av tilstanden, som er basert på et sett kliniske kriterier og der supplerende prøver, inkludert allergitesting, har begrenset plass. Behandlingsmodellen foreslås fortsatt å være dualistisk med på den ene side vekt på å gjenopprette barrierefunksjonen og på den annen å dempe inflammasjonen. Innen begge feltene kan vi vente oss nye og mer spesifikke medikamenter.

Dermatologic immunity kan ved første øyekast virke informasjonsmettet og en smule uoverkommelig for den klinisk praktiserende dermatolog. Mange av kapitlene synes også lite relevante for den daglige praksis og er kanskje til størst nytte for leger med spesiell forskningsinteresse innen det immunologiske feltet, men her blir den kanskje for summarisk? På den annen side 